\title{
The Relevance of Tag along Rights and Identity of Controlling Shareholders for the Price Spreads between Dual-Class Shares: the Brazilian Case
}

\author{
Richard Saito * \\ E-mail address: rsaito@fgvsp.br \\ Escola de Administração de Empresas de São Paulo/Fundação Getúlio Vargas \\ São Paulo, SP, Brazil.
}

\author{
Alexandre Di Miceli da Silveira \\ E-mail address: alexfea@usp.br \\ Faculdade de Economia, Administração e Contabilidade/Universidade de São Paulo \\ São Paulo, SP, Brazil.
}

\begin{abstract}
This paper analyzes the determinants of the differential pricing of equity classes (the so-called dual-class premium [DCP]) in Brazil from 1995 to 2006 with a focus on two specific corporate governance aspects: i) the granting of tag along rights, a mandatory bid rule that extends to minority shareholders the right to sell their shares in case of a control transfer; and ii) the identity of the controlling shareholders, with an emphasis on family control. We examined 87 Brazilian listed firms throughout the period, resulting in a sample of 3,287 observations. We found empirical evidence that changes in Corporate Law decreased (increased) the advantage of voting shares in terms of tag along rights reduced (incremented) DCP. However, we did not find empirical evidence that the voluntary granting of tag along rights altered DCP. We also found evidence suggesting that family control is positively associated with DCP level. Overall, our results indicate that regulations regarding shareholders' rights and the identity of controlling shareholders are the two relevant corporate governance variables for DCP level in environments characterized by concentrated ownership structures.
\end{abstract}

Key words: voting and non-voting shares; dual class premium; private benefits of control; legal rules; mandatory bid Rule.

Received 02 October 2008; received in revised form 10 June 2009.

Copyright (C) 2010 Brazilian Administration Review. All rights reserved, including rights for translation. Parts of this work may be quoted without prior knowledge on the condition that the source is identified.

\footnotetext{
* Corresponding author: Richard Saito

EAESP/FGV, Avenida 9 de Julho, 2029, Bela Vista, São Paulo, SP, 01313-100, Brazil.
} 


\section{INTRODUCTION}

Two different equity classes of a single firm with the same cash-flow rights but different voting rights should lead to equal pricing ${ }^{(1)}$. However, a series of theoretical and empirical studies have shown that a price premium (the so called voting premium or VP) could exist for voting shares over non-voting shares of a single firm ${ }^{(2)}$. These empirical results are explained by two main arguments: 1) that controlling shareholders can extract private benefits of control (which would lead to a positive relation between the amount of these private benefits and VP); and 2) that voting shares could be important in a takeover contest, seizing a fraction of the premium to be paid by eventual acquirers ${ }^{(3)}$ (which would lead to a positive relationship between the probability of voting shares being important for acquirers and VP). Caprio and Croci (2008, p. 5) summarize this discussion, arguing that wellestablished literature suggests that the main determinants of the price differential between voting and non-voting shares are the presence of private benefits of control and the probability that the incumbent will be dispossessed of control by someone who accumulates a larger voting block.

In the case of firms with dispersed ownership such as large Anglo-Saxon companies, competition for control can be intense, and marginal shareholders are crucial in control contests. On the other hand, for firms with concentrated ownership, such as all Brazilian firms analyzed in this paper, marginal voting shareholders do not play any pivotal role in control contests since controlling shareholders always have a majority of outstanding voting shares ${ }^{(4)}$. As a consequence, the differential pricing between voting and non-voting shares would be solely due to the probability of extraction of private benefits of control and to the difference of some observable rights attached to different equity classes (such as different dividends, mandatory bid rule, liquidity differentials, etc.).

Corroborating the hypothesis that the relative value of voting shares against non-voting shares can be seen as a proxy for the level of private benefits extracted by controlling shareholders, several previous researches have found lower VP for firms located in countries with stronger investor protection. Specifically, for countries considered to have stronger investor protection, VP ranged between $0-20 \%{ }^{(5)}$, whereas for countries considered to have weaker investor protection VP ranged between $50-100 \%{ }^{(6)}$. The negative relationship between the quality of investor protection and the level of voting premium was further confirmed by Nenova (2003) after analyzing data of 661 companies from 18 countries. Doidge (2004) also corroborated the above hypothesis, finding that VP is lower for firms that cross-listed their shares in markets with higher corporate governance standards, therefore committing themselves to reducing the level of private benefits to be extracted by their controlling shareholders.

In Brazil, contrary to most equity markets, voting shares are reported to have been traded at a discount relative to non-voting shares (Silva \& Subrahmanyam, 2007) ${ }^{(7)}$. There are four main reasons for this result: i) both papers only analyze voting shares available for trading in the market, therefore not taking into account the implicit voting premium held by the shares of controlling shareholders; ii) non-voting shares usually have higher liquidity levels than voting shares; and iii) for most firms, the dividend paid for non-voting shares is $10 \%$ higher than for voting shares. As a result, we cannot consider the price differential between voting and non-voting shares floating in the market in Brazil as an accurate measure of the voting premium. Rather, it simply corresponds to a dual class premium [DCP] between two share classes, which will be the term we will use henceforth.

In recent years, Brazilian firms have seen important changes in the relative rights of voting shares against non-voting shares, which could have impacted DCP. These changes are related to the concept of mandatory bid rule, in which minority shareholders have the right to receive at least a given percentage of the price paid by controlling shareholders in case of selling their control stake. The mandatory bid rule is known in Brazil as the tag along right which will be the term that we will use henceforth. 
On the one hand, firms have seen changes in corporate law that can be considered exogenous events. Prior to May 1997, the acquirer of a control block was required to make an offer to the remaining voting shareholders at the same price offered to controlling shareholders. Therefore, under the original corporate law (Law n. 6.404, 1976), a tag along right of $100 \%$ for minority voting shareholders was in place. However, Law 9.457, enacted in May 1997, amended the previous corporate law, abolishing tag along rights ${ }^{(8)}$. Finally, a new amendment to corporate law, Law 10.303, enacted in October 2001, partially reinstated tag along rights for minority voting shareholders, this time with $80 \%$ of the price paid for the shares of the controlling block. On the other hand, since 2001 some firms have voluntarily decided to grant tag along rights to minority shareholders (even non-voting shareholders) beyond law requirements in Brazil. This decision was taken as part of the process that some firms carried out to adopt the so-called best corporate governance practices ${ }^{(9)}$. Therefore, we have also seen an endogenous decision leading to a different balance of rights between voting and non-voting shares throughout this period, which could have impacted DCP in Brazil.

In sum, the Brazilian case is interesting for three reasons: i) the issuance of non-voting shares is widespread; ii) there is a large wedge between voting rights and cash flow rights held by controlling shareholders ${ }^{(10)}$; and, iii) the country witnessed exogenous events (two changes in corporate law) as well as endogenous ones (voluntary granting of tag along rights by firms willing to improve their corporate governance practices) that changed the level of tag along rights throughout the research period (1995 to 2006). Besides the exogenous and endogenous changes regarding mandatory bid rules, about half of Brazilian listed firms are controlled by families ${ }^{(11)}$, which could possibly impact DCP. This hypothesis was recently tested by Caprio and Croci (2008) in Italy. The authors argue that the role of family control is an important factor in explaining DCP, ignored by previous literature ${ }^{(12)}$.

In short, we aim to answer two main questions, which constitute the main contributions of this paper: 1) How do exogenous and endogenous changes in a specific corporate governance device, called tag along rights, impact DCP over time in Brazil?; and, 2) Does the identity of the controlling shareholder matter for the level of DCP?

Regarding the first question, our empirical results suggest that the enactment of corporate laws have a significant influence on DCP. Specifically, exogenous legal changes that increased (decreased) the relative advantage of voting shares vis-à-vis non-voting shares regarding tag along rights increased (decreased) DCP in Brazil. However, we did not find robust evidence that voluntary granting of tag along rights (an endogenous change promoted by firms) influences DCP level in our sample. Regarding the second question, we found a positive relation between family control and DCP. This result is in line with the results obtained regarding the Italian market by Caprio and Croci (2008).

Besides the two main results, other results stand out: i) we observed a significant variation in DCP in Brazil during our sample period, ranging from a mean (median) of $17.97 \%$ (4.95\%) in 1996 to $-2.87 \%$ $(-6.93 \%)$ in 2000; ii) liquidity and dividend differentials between voting and non-voting shares play a significant role in explaining DCP; and, iii) the concentration of both control rights and cash flow rights by controlling shareholders influences the DCP level.

The paper is structured as follows: we initially present some background on the institutional framework in Brazil, including the main changes from 1995 to 2006, as well as results from recent papers on this field of research. We then proceed with the methodological detailing of the paper, including the research model and variable definitions. After the methodology section, we present and discuss the main empirical results, with the final section providing the concluding remarks.

\section{INSTITUTIONAL FRAMEWORK IN BRAZIL}

The main differences between voting and non-voting shares in Brazil are stated by Law 6.404/1976 (Original Corporate Law). This Law had important amendments in May 1997 by Law 9.457/1997 and 
in October 2001 by Law 10.303/2001. This section provides some evidence on how the changes in corporate law altered the balance of rights between voting and non-voting shares in Brazil from 1995 to 2006.

\section{Prior to May 1997}

Law 6.404/1976, enacted in December 1976, governed Brazilian corporations without changes until 1997. The Law allowed firms to issue common (voting) shares and preferred (non-voting) shares. Non-voting shares could constitute up to two thirds of total outstanding shares, meaning that controlling shareholders could directly own only $16.7 \%$ of the total share capital in order to assure control. Article 254 of the Law required a mandatory offer for all outstanding voting shares in case of a control transfer at the same price and terms of the control block shares. The original Corporate Law also set a mandatory minimum dividend payment of $25 \%$ of net income. As an additional protection for non-voting shareholders, if the company fails to distribute dividends for three years in a row (e.g. due to losses), preferred non-voting shareholders acquire full voting rights until the firm starts repaying dividends.

\section{May 1997 Amendments to the Corporate Law}

To avoid likely lawsuits from minority shareholders during the privatization process, Brazilian Congress approved amendments to the Corporate Law - known as Law 9.457/1997 - in May 1997. This new legal framework repealed Article 254, making it no longer necessary that the acquirer had to make a public offer to buy all outstanding voting shares under the same terms as those offered to previous controlling shareholders. To mitigate the impact on minority shareholders, the new regulation entitled preferred non-voting shareholders to an additional 10\% in dividends compared to those paid to ordinary voting shareholders ${ }^{(13)}$.

\section{October 2001 Amendments to the Corporate Law}

Law 10.303/2001, enacted in October 2001, was designed to minimize the negative impacts of the previous legislation (Law n. 9.457, 1997). Among other new clauses, it partially reinstated tag along rights for voting shares, assuring minority voting shareholders an offer of at least $80 \%$ of the price paid for control block shares. Furthermore, Law 10.303/2001 reduced the maximum ratio of nonvoting shares from two-thirds to one-half of total capital ${ }^{(14)}$, and allowed firms to choose among three different benefits to be granted to non-voting shares as a compensation for the absence of voting rights: (a) a priority minimum dividend of $3 \%$ of the book value per share, (b) dividends $10 \%$ higher than voting shares, (c) tag along rights similar to the voting shares $(80 \%$ of the price paid for the controlling block). In spite of the three options available for non-voting shares, the vast majority of firms chose to maintain the differentiated dividends for non-voting shares as the extra-benefit for this class of stock. Finally, it is important to note that non-voting shares have never been required by Corporate Law to be under tag along rights in Brazil.

\section{Literature ReVIEW AND DeterminANTS OF DUAL-CLASS SPREAD}

Several studies have attempted to evaluate the determinants of the dual class premium. Next, we present the results of papers we consider more compatible with our focus and methodology. Based on these works, we then present the hypothesis regarding the potential determinants tested in our paper.

Nenova (2001) is the first paper to estimate the value of the control block in Brazil. She found that the control value for listed Brazilian companies was directly affected by changes in the legal protection for minority shareholders. Specifically, she observed that the control value increased more 
than twice with the enactment of Law 9.457/1997 (which weakened minority investor protection). Two years later, control value dropped to pre-1997 levels in response to CVM Instruction 299/1999, which reinstated the minority protection laws scrapped by the previous legal change ${ }^{(15)}$. The author also found evidence that majority shareholders shared some of the benefits they extracted with minority voting shareholders in detriment of minority non-voting shareholders.

Damodaran (2005) created a model to estimate the fair value of voting shares vis-à-vis non-voting shares. According to this author, the difference in price between two share classes should be a function of the expected value of control. This, in turn, would be a function of the probability of a change in management at that firm and the value of changing management. Based on this model, the author made several testable predictions. For our paper, the most important ones are: i) The difference between voting and non-voting shares should go to zero if there is no chance of changing management/control. This will clearly be a function of the concentration of ownership of the voting shares. If there are relatively few voting shares, held entirely by insiders, voting shares should trade at the same price as non-voting shares. ii) Other things remaining equal, the smaller the number of voting shares relative to nonvoting shares, the higher the premium for voting shares. Since the expected value of control is divided by the number of voting shares to receive the premium, the smaller that number, the greater the value attached to each share.

Caprio and Croci (2008) examined the dual class premium in Italy from 1974 to 2003, a period during which the premium fluctuated widely in the country, ranging from $1 \%$ to $100 \%$. They found that family firms have higher DCP, especially when the family owns a large stake in the company's voting equity. They explain this result based on two arguments: i) that families have a higher attachment to control (probably reacting more vigorously to potential threats of takeover by purchasing additional voting shares); and ii) that families are more prone than other types of controlling shareholders to expropriate the non-voting class of shareholders.

Linciano (2003) also analyzes the dual class premium in the Italian market, examining the effects of changes in the mandatory bid rule introduced there in 1992. This rule allowed minority voting shareholders to receive the same price per share in an acquisition paid by controlling shareholders. However, this right was not extended to non-voting shareholders. The author found an increase of around $2 \%$ in the premium on voting shares.

Ødegaard (2006) analyzed the dual class premium in Norway. Differently from the majority of papers in this line of research. But in line with previous results found in the Brazilian market, he found, for part of the sample period, nonvoting trading at a premium to voting stock. According to the author, this was due some unique features of Norwegian corporate law that restricted the access of foreigners only to nonvoting stocks, pushing up the price of these shares. In short, he found evidence that the effects stemming from market segmentation and liquidity could sometimes outweigh the corporate governance effects.

Nenova (2003) conducted a cross-country analysis of 661 companies from 18 countries. She developed a methodology to compute the voting premium associated with a controlling block of shares based on the difference between the market prices of different classes of shares. The voting premium ranged from $-5 \%$ in Finland to $36.5 \%$ in Mexico across the countries. Overall, she found that countries with strong law enforcement, good investor protection indices and pro-investor takeover rules have lower voting premiums.

Finally, Adams and Ferreira (2007) made a comprehensive survey of the empirical economic literature on disproportional ownership, including the dual class premium. The authors argued that there are two mains approaches to estimating the control block premium. The first one is to infer it from the difference between the market value of different classes of voting shares. The second approach is to infer the control premium from sales of controlling blocks (Dyck \& Zingales, 2004, provide an example of application of the second approach). 
In this paper, we measure DCP using the first approach, which has been the most popular in the literature. Therefore, the dual class premium is computed as follows:

$D C P_{i t}=\frac{P_{i t}^{v}-P_{i t}^{n v}}{P_{i t}^{n v}}$

Equation 1

where $P_{i t}^{v}\left(P_{i t}^{n v}\right)$ is the price of voting (non-voting) share of company $i$ in period t.

Based on the research presented and on the rationale displayed in Table 1, we developed the following main testable hypotheses for our paper regarding the potential determinants of the dual class premium:

Hypothesis 1: Law 9.457/1997, which excluded tag along rights for minority voting shareholders, had a negative impact on DCP.

Hypothesis 2: Law 10.303/2001, which partially reinstated tag along rights only for minority voting shareholders, had a positive impact on DCP.

Hypothesis 3: The voluntary granting of tag along rights for both voting and non-voting shares, or exclusively for non-voting shares, had a negative impact on DCP.

Hypothesis 4: Family control is positively associated with DCP, since families have a higher attachment to control and are more prone than other types of controlling shareholders to expropriate non-voting shareholders (Caprio \& Croci, 2008).

Hypothesis 5: State-owned control is negatively associated with DCP since there is a lower probability of these firms being acquired.

Besides the five main hypotheses related to the mandatory and voluntary granting of tag along rights, and the type of controlling shareholders, we also developed other hypotheses usually tested in the related DCP literature:

Hypothesis 6: The higher the dividend differential in favor of non-voting shares, the lower the DCP; Hypothesis 7: The higher the liquidity for non-voting shares relative to voting shares, the lower the DCP; Hypothesis 8: The ratio of voting shares (control rights) held by controlling shareholders is negatively associated with DCP, due to the reduction of the probability of a takeover taking place (Damodaran, 2005), and the negative impact on the liquidity of voting shares; Hypothesis 9: The ratio of total shares (cash flow rights) held by controlling shareholders is positively associated with DCP, since it will be associated with lower levels of private benefits of control; Hypothesis 10: For lower levels of financial leverage, the price differential between voting and non-voting stock should rise due to the potential extraction of larger private benefits of control. For higher levels of financial leverage, the relation should reverse due to an increasing risk of bankruptcy and then control change to debt claimants (Saito, 2003); Hypothesis 11: Firms' size is negatively associated with DCP, since larger firms are less likely to experience control transfers.

Table 1 summarizes all the potential DCP determinants tested, including the operational definition of the variables, rationale and expected sign of the coefficients. 
Table 1

Summary of Research Variables, Operational Definitions, and Rationale for Expected Coefficients' Signs

\begin{tabular}{|c|c|c|c|c|c|}
\hline \# & Code & Name of Variable & Operational Definition & Expected Sign & Rationale \\
\hline 1 & DCP & $\begin{array}{c}\text { Dual class } \\
\text { premium - } \\
\text { weighted average } \\
\text { of share price }\end{array}$ & $\begin{array}{l}\text { (weighted average of } \\
\text { quarterly prices of ON } \\
\text { shares*- weighted } \\
\text { average of quarterly prices } \\
\text { of PN shares during the } \\
\text { quarter) / weighted } \\
\text { average of quarterly prices } \\
\text { of PN shares }\end{array}$ & $\begin{array}{l}\text { NA } \\
\text { (dependent } \\
\text { variable) }\end{array}$ & NA \\
\hline 2 & LIQ_vol & $\begin{array}{l}\text { Liquidity difference } \\
\text { between ON and PN } \\
\text { share classes } \\
\text { (financial volume) }\end{array}$ & $\begin{array}{l}\text { In (quarterly financial } \\
\text { volume of ON shares / } \\
\text { quarterly financial } \\
\text { volume of PN shares) }\end{array}$ & + & $\begin{array}{l}\text { Largest financial volumes } \\
\text { of ON shares relative to PN } \\
\text { shares will lead to a larger } \\
\text { dual class premium. }\end{array}$ \\
\hline 3 & LIQ_neg & $\begin{array}{l}\text { Liquidity } \\
\text { difference between } \\
\text { ON and PN share } \\
\text { classes (Bovespa } \\
\text { liquidity index) }\end{array}$ & $\begin{array}{l}\text { In (quarterly Bovespa } \\
\text { liquidity index of ON } \\
\text { shares / quarterly } \\
\text { Bovespa liquidity index } \\
\text { of PN shares) }\end{array}$ & + & $\begin{array}{l}\text { Largest liquidity index of } \\
\text { ON shares relative to PN } \\
\text { shares will lead to a larger } \\
\text { dual class premium. }\end{array}$ \\
\hline 4 & ON_conc & $\begin{array}{l}\text { Percentage of } \\
\text { voting shares held } \\
\text { by three largest } \\
\text { shareholders** }\end{array}$ & $\begin{array}{l}\text { Sum of ON shares held } \\
\text { by three largest } \\
\text { shareholders divided by } \\
\text { total ON shares issued }\end{array}$ & - & $\begin{array}{l}\text { Higher concentration of voting } \\
\text { shares will negatively impact } \\
\text { the liquidity of ON shares and } \\
\text { reduce the probability of a } \\
\text { takeover taking place } \\
\text { (Damodaran, 2005), thus } \\
\text { negatively impacting dual } \\
\text { class premium. }\end{array}$ \\
\hline 5 & TS_conc & $\begin{array}{l}\text { Percentage of total } \\
\text { shares held by } \\
\text { three largest } \\
\text { shareholders }\end{array}$ & $\begin{array}{l}\text { Sum of total shares held } \\
\text { by three largest } \\
\text { shareholders divided by } \\
\text { total shares issued }\end{array}$ & - & $\begin{array}{l}\text { Higher percentage of total } \\
\text { shares (cash flow rights) held } \\
\text { by controlling shareholders } \\
\text { will be associated with lower } \\
\text { levels of private benefits of } \\
\text { control, leading to a small } \\
\text { dual class premium. }\end{array}$ \\
\hline 6 & RAT_ON & $\begin{array}{l}\text { Ratio of ON shares } \\
\text { to the company's } \\
\text { total capital }\end{array}$ & $\begin{array}{l}\text { Number of ON shares } \\
\text { divided by the total } \\
\text { number of outstanding } \\
\text { shares (ON and PN) }\end{array}$ & ambiguous & $\begin{array}{l}\text { The use of non-voting shares } \\
\text { in the firms' capital enables } \\
\text { the controlling shareholder to } \\
\text { leverage resources with non- } \\
\text { voting shareholders. } \\
\text { Therefore, this shareholding } \\
\text { leverage implies larger } \\
\text { private benefits of control, } \\
\text { leading to higher dual class } \\
\text { premiums. On the other } \\
\text { hand, Damodaran (2005) } \\
\text { argues that, since the } \\
\text { expected value of control is } \\
\text { divided by the number of } \\
\text { voting shares to get the } \\
\text { premium, the smaller that } \\
\text { number, the greater the value } \\
\text { attached to each share. }\end{array}$ \\
\hline
\end{tabular}


Table 1 (continued)

\begin{tabular}{|c|c|c|c|c|c|}
\hline$\#$ & Code & Name of Variable & Operational Definition & Expected Sign & Rationale \\
\hline 7 & DIV_DIF & $\begin{array}{l}\text { Difference of } \\
\text { dividends paid to } \\
\text { voting }(\mathrm{ON}) \text { and } \\
\text { non-voting }(\mathrm{PN}) \\
\text { shares }\end{array}$ & $\begin{array}{c}\text { (Dividends paid to ON } \\
\text { shares - Dividends paid } \\
\text { to PN shares) / } \\
\text { Dividends paid to PN } \\
\text { shares }\end{array}$ & + & $\begin{array}{l}\text { A larger dividend differential } \\
\text { favoring PN shares relative to } \\
\text { dividends paid to ON shares } \\
\text { will lead to a small dual class } \\
\text { premium. }\end{array}$ \\
\hline 8 & $\begin{array}{l}\text { DUM_- } \\
\text { DIV }\end{array}$ & $\begin{array}{l}\text { Dummy indicating } \\
\text { if ON shares } \\
\text { received the same or } \\
\text { superior dividends } \\
\text { regarding PN shares }\end{array}$ & $\begin{array}{c}\text { DUM_DIV = } 1 \text { if ON } \\
\text { shares quarterly dividends } \\
\text { were larger or the same as } \\
\text { the PN shares' quarterly } \\
\text { dividends; } 0 \text { for larger PN } \\
\text { dividends }\end{array}$ & + & $\begin{array}{l}\text { An absence of a positive } \\
\text { dividend differential } \\
\text { favoring PN shares relative } \\
\text { to ON shares will lead to a } \\
\text { small dual class premiums }\end{array}$ \\
\hline 9 & $\operatorname{lnTA}$ & $\begin{array}{l}\text { Firm's size - } \\
\text { Natural logarithm } \\
\text { of total assets }\end{array}$ & ln (total assets) & - & $\begin{array}{l}\text { Larger firms will have a } \\
\text { low likelihood of control } \\
\text { transfers, leading to a small } \\
\text { dual class premium. }\end{array}$ \\
\hline 10 & $\begin{array}{l}\text { Lever } \\
\text { and } \\
\text { Lever_- } \\
\text { quad }\end{array}$ & Financial leverage & $\begin{array}{l}\text { Long term financial } \\
\text { liabilities / total assets }\end{array}$ & $\begin{array}{l}\text { + linear, - } \\
\text { quadratic }\end{array}$ & $\begin{array}{l}\text { Low levels of debt will } \\
\text { positively influence dual } \\
\text { class premium. However, } \\
\text { higher levels of financial } \\
\text { leverage could increase the } \\
\text { likelihood of control transfers } \\
\text { to creditors, diminishing the } \\
\text { voting premium. }\end{array}$ \\
\hline 11 & $\begin{array}{l}\text { Ind } \\
1 \ldots 17\end{array}$ & $\begin{array}{l}\text { Set of industry } \\
\text { dummies }\end{array}$ & $\begin{array}{l}\text { Seventeen binary } \\
\text { variables indicating the } \\
\text { firm's industry }\end{array}$ & N.A. & $\begin{array}{l}\text { Industry can influence the } \\
\text { probability of control } \\
\text { transfers and M\&A } \\
\text { activity, influencing dual } \\
\text { class premiums }\end{array}$ \\
\hline 12 & $\begin{array}{l}\text { Law } \\
6404\end{array}$ & $\begin{array}{l}\text { Dummy variable } \\
\text { for Law 6404/76 }\end{array}$ & $\begin{array}{l}\text { Law } 6404=1 \text { if the } \\
\text { quarter of analysis is } \\
\text { within first quarter } \\
1994 \text { and first quarter } \\
1997, \text { prior to Law } \\
9457 \text { (when Article } 254 \\
\text { of Law } 6404 \text { was in } \\
\text { force), } 0 \text { otherwise }\end{array}$ & + & $\begin{array}{l}\text { With the passing of Law } \\
9457, \text { the mandatory bid } \\
\text { rule for ON shares } \\
\text { prescribed in Article } 254 \\
\text { was revoked, negatively } \\
\text { influencing dual class } \\
\text { premium. With the } \\
\text { approval of Law } 10303 \text {, } \\
\text { Article } 254 \text { was reinstated }\end{array}$ \\
\hline 13 & $\begin{array}{l}\text { Law } \\
9457\end{array}$ & $\begin{array}{l}\text { Dummy variable } \\
\text { for Law 9457/97 }\end{array}$ & $\begin{array}{l}\text { Law } 9457=1 \text { if the } \\
\text { quarter of analysis is } \\
\text { within second quarter } \\
1997 \text { and third quarter } \\
\text { 2001, prior to Law } 10303 \\
\text { (when Article } 254 \text { was } \\
\text { revoked), } 0 \text { otherwise }\end{array}$ & - & $\begin{array}{l}\text { prescribing an } 80 \% \\
\text { mandatory bid rule for ON } \\
\text { shares, therefore positively } \\
\text { influencing dual class } \\
\text { premium. }\end{array}$ \\
\hline 14 & $\begin{array}{l}\text { Law } \\
10303\end{array}$ & $\begin{array}{l}\text { Dummy variable } \\
\text { for Law 10303/01 }\end{array}$ & $\begin{array}{l}\text { Law } 10303=1 \text { for } \\
\text { quarter of analysis from } \\
\text { fourth quarter } 2001 \text { on, } \\
\text { (when Article } 254 \text { was } \\
\text { reinstated), } 0 \text { otherwise }\end{array}$ & + & \\
\hline
\end{tabular}


Table 1 (continued)

\begin{tabular}{|c|c|c|c|c|c|}
\hline$\#$ & Code & Name of Variable & Operational Definition & Expected Sign & Rationale \\
\hline 15 & Tag_pn & $\begin{array}{l}\text { Additional tag } \\
\text { along rights } \\
\text { (mandatory bid } \\
\text { rule) voluntarily } \\
\text { granted only for } \\
\text { PN shares }\end{array}$ & $\begin{array}{l}\text { Tag_pn }=1 \text { if the firm } \\
\text { voluntarily grants tag } \\
\text { along rights only for } \\
\text { PN shares, without any } \\
\text { additional tag along for } \\
\text { ON shares beyond what } \\
\text { is required by Law } \\
(80 \%), 0 \text { otherwise }\end{array}$ & - & $\begin{array}{l}\text { The granting of tag along } \\
\text { rights only for PN shares } \\
\text { diminishes the relative } \\
\text { advantage of ON shares, } \\
\text { negatively influencing dual } \\
\text { class premium }\end{array}$ \\
\hline 16 & $\begin{array}{c}\text { Tag_on } \\
\text { pn }\end{array}$ & $\begin{array}{l}\text { Additional tag } \\
\text { along rights } \\
\text { voluntarily granted } \\
\text { both for ON and } \\
\text { PN shares }\end{array}$ & $\begin{array}{c}\text { Tag_onpn }=1 \text { if the } \\
\text { firm voluntarily grants } \\
\text { tag along rights both for } \\
\text { ON and PN shares, } 0 \\
\text { otherwise }\end{array}$ & - & $\begin{array}{l}\text { The granting of tag along } \\
\text { rights both for ON and PN } \\
\text { also should negatively } \\
\text { influence dual class } \\
\text { premium, since the marginal } \\
\text { gain for ON shares (which } \\
\text { start from a Law prescribed } \\
\text { tag along of 80\%) would be } \\
\text { substantially smaller than } \\
\text { the marginal gain for PN } \\
\text { shares }\end{array}$ \\
\hline 17 & $\begin{array}{c}\text { Tag_Al } \\
\text { ong }\end{array}$ & $\begin{array}{l}\text { Any additional tag } \\
\quad \text { along rights } \\
\text { voluntarily granted }\end{array}$ & $\begin{array}{c}\text { Tag_Along = } 1 \\
\text { Tag_onpn }=1 \text { if the } \\
\text { firm voluntarily grants } \\
\text { any tag along rights } \\
\text { beyond what is required } \\
\text { by Law (sum of } \\
\text { Tag_onpn and Tag_pn } \\
\text { variables), } 0 \text { otherwise }\end{array}$ & - & $\begin{array}{l}\text { The granting of tag along } \\
\text { rights in any circumstance } \\
\text { diminishes the relative } \\
\text { advantage of ON shares, } \\
\text { negatively influencing the } \\
\text { dual class premium }\end{array}$ \\
\hline 18 & FAM & $\begin{array}{l}\text { Family Owned } \\
\text { Firm }\end{array}$ & $\begin{array}{c}\text { FAM = } 1 \text { if a family (or } \\
\text { a group of families } \\
\text { formally united by a } \\
\text { shareholders } \\
\text { agreement) controls } \\
\text { more than } 50 \% \text { of } \\
\text { voting shares, } 0 \\
\text { otherwise }\end{array}$ & + & $\begin{array}{l}\text { Family control associated } \\
\text { with a higher probability of } \\
\text { extraction of private benefits } \\
\text { of control (Caprio \& Croci, } \\
\text { 2008). }\end{array}$ \\
\hline 19 & SOE & $\begin{array}{l}\text { State Owned } \\
\text { Enterprise }\end{array}$ & $\begin{array}{c}\mathrm{SOE}=1 \text { if government } \\
\text { controls more than } 50 \% \\
\text { of voting shares, } 0 \\
\text { otherwise }\end{array}$ & - & $\begin{array}{l}\text { State owned firms having a } \\
\text { smaller probability of being } \\
\text { acquired, leading to a small } \\
\text { voting premium. }\end{array}$ \\
\hline
\end{tabular}

Note. * The average quarterly price of each share class was calculated based on the rolling weighted average of closing share prices for a period of $\mathrm{n}$ traded days: $\mathrm{WA}=(\mathrm{P}[\mathrm{t}] * \mathrm{~N}+\mathrm{P}[\mathrm{t}-1] *(\mathrm{~N}-1)+\mathrm{P}[\mathrm{t}-2] *(\mathrm{~N}-2)+\ldots+\mathrm{P}[\mathrm{t}-\mathrm{N}]) / \mathrm{N}+(\mathrm{N}-1)+(\mathrm{N}-2)+\ldots$ $+(\mathrm{N}-\mathrm{N})$. Where: $\mathrm{WA}=$ weighted average, $\mathrm{P}[\mathrm{t}]=$ share price at date $t, \mathrm{P}[\mathrm{t}-1]=$ share price at date $\mathrm{t}-1, \mathrm{~N}=$ number of share traded days throughout the quarter. The idea was to take into account the share price throughout the quarter, imputing more relevance to the last days of the period. ** We only analyzed the direct ownership structure for all ownership variables (ON_conc, PN_conc, and TS_conc). 


\section{ReseARCh Methodology}

\section{Sample and Data Collection}

The sample consists of 87 financial and non-financial firms listed at the São Paulo Stock Exchange (Bovespa) with dual class shares from $1^{\text {st }}$ quarter 1995 to $3^{\text {rd }}$ quarter 2006. These firms are selected after exclusions based on: i) lack of a minimal level of liquidity of voting and non-voting shares; ii) negative book value of equity; and, iii) incomplete or unavailable market and/or accounting information. The data is computed by quarters ${ }^{(16)}$, resulting in an unbalanced panel of 3,287 firmquarterly observations. All data was collected using the Economatica database ${ }^{(17)}$. The variable representing DCP is winsorized at $2.5 \%$ level $^{(18)}$.

\section{Research Model}

Based on the potential determinants of DCP, we estimated the following model using Pooled OLS and Fixed Effects panel data regressions ${ }^{(19)}$. Details of operational definitions of all variables presented below are presented in Table 1.

$$
\begin{aligned}
& D C P_{i t}=\beta_{0}+\beta_{1} D I F_{-} L I Q_{i t}+\beta_{2} D I F_{-} D I V_{i t}+\beta_{3} O N_{-} \text {conc }_{i t}+\beta_{4} T S_{-} \text {conc }_{i t}+\beta_{5} R A T_{-} O N_{i t}+\beta_{6} \ln T A_{i t} \quad \text { Equation } 2 \\
& +\beta_{7} L E V E R_{i t}+\beta_{8} L E V E R_{i t}^{2}+\beta_{9} L A W 6404_{i t}+\beta_{10} L A W 9457_{i t}+\beta_{11} L A W 10303_{i t}+\beta_{12} T A G_{-} A L O N G_{i t}+ \\
& +\beta_{13} F A M_{i t}+\beta_{14} S O E_{i t}+\sum_{j=1}^{17} \delta_{j} \operatorname{IND}_{j i t}+u_{i}+\varepsilon_{i t}
\end{aligned}
$$

\section{Where:}

Dual Class Premium [DCP]; DIF_LIQ - liquidity differential between voting and nonvoting shares (proxied by LIQ_vol or LIQ_neg variables alternatively); DIF_DIV - dividend differential between voting and non-voting shares; ON_conc - controlling shareholder stake of voting shares; TS_conc controlling shareholder stake of total shares; RAT_ON - ratio of voting shares to total shares outstanding; lnTA - firms' size (proxied by Total Assets); LEVER - Financial leverage; LAW6404, LAW9457, and LAW 10303 - dummy variables associated with validity of tag along clauses enacted by laws 6.404/1976, 9.457/1997, and 10.303/2001, respectively; TAG_ALONG - dummy variable that equals 1 if the firm has voluntarily granted tag along rights; FAM - dummy variable that equals 1 if the firm is family controlled; SOE - dummy variable that equals 1 if the Government is the controlling shareholder; IND - series of 17 industry dummies (according to Economatica ${ }^{\circledR}$ database classification).

In Equation 2, $i$ represents the firm and $t$ the respective quarter (with $t=1,2, \ldots, 48$ ). $\varepsilon_{i t}$ is the random error term from the $\mathrm{i}$-th firm in the $\mathrm{t}$-th quarter. The term $u_{i}$ captures unobserved firm characteristics that do not vary over time. Based on the hypothesis summarized in Table 1 , we expect statistically significant coefficients with the following signs: $\beta_{1}, \beta_{2}, \beta_{7}, \beta_{9}, \beta_{11}, \beta_{13}>0 ; \beta_{3}, \beta_{4}, \beta_{6}, \beta_{8}, \beta_{10}, \beta_{12}, \beta_{14}<0$; Since the direction of the relationship between the ratio of voting shares over total shares outstanding shares and DCP is ambiguous, we do not have an expected sign for the coefficient $\beta_{5} ; \delta$ are coefficients related to several binary industry control variables. 


\section{RESULTS}

\section{Descriptive Statistics}

Initially, we present in Table 2 some descriptive statistics with the evolution of DCP from 1995 to 2006 in Brazil.

Table 2

Dual Class Premium from First Quarter 1995 to Last Quarter 2006

Dual class premium

\begin{tabular}{ccccccc}
\cline { 2 - 6 } Year & Mean & Median & Minimum & Maximum & $\begin{array}{c}\text { Std. } \\
\text { Deviation }\end{array}$ & $\begin{array}{c}\text { \# of } \\
\text { Firms }\end{array}$ \\
\hline 1995 & $15.00 \%$ & $7.29 \%$ & $-47.50 \%$ & $111.08 \%$ & $33.88 \%$ & 40 \\
1996 & $17.97 \%$ & $4.95 \%$ & $-52.16 \%$ & $180.32 \%$ & $41.45 \%$ & 44 \\
1997 & $10.81 \%$ & $4.37 \%$ & $-50.37 \%$ & $165.73 \%$ & $35.54 \%$ & 44 \\
1998 & $11.98 \%$ & $2.13 \%$ & $-57.71 \%$ & $262.66 \%$ & $48.49 \%$ & 53 \\
1999 & $-0.30 \%$ & $-6.78 \%$ & $-77.37 \%$ & $224.59 \%$ & $46.63 \%$ & 65 \\
2000 & $-2.87 \%$ & $-6.93 \%$ & $-61.55 \%$ & $200.89 \%$ & $33.17 \%$ & 74 \\
2001 & $9.04 \%$ & $1.62 \%$ & $-54.63 \%$ & $167.21 \%$ & $31.67 \%$ & 79 \\
2002 & $8.47 \%$ & $0.30 \%$ & $-45.78 \%$ & $122.11 \%$ & $31.02 \%$ & 82 \\
2003 & $5.13 \%$ & $-1.33 \%$ & $-45.49 \%$ & $245.20 \%$ & $33.20 \%$ & 83 \\
2004 & $5.38 \%$ & $-2.32 \%$ & $-64.74 \%$ & $181.91 \%$ & $33.18 \%$ & 85 \\
2005 & $9.11 \%$ & $0.34 \%$ & $-44.45 \%$ & $252.75 \%$ & $38.05 \%$ & 87 \\
2006 & $10.52 \%$ & $1.07 \%$ & $-45.52 \%$ & $239.48 \%$ & $33.85 \%$ & 87 \\
$\mathbf{1 9 9 5 - 2 0 0 6}$ & $\mathbf{7 . 6 8 \%}$ & $\mathbf{- 0 . 0 6 \%}$ & $\mathbf{- 7 7 . 3 7 \%}$ & $\mathbf{2 6 2 . 6 6 \%}$ & $\mathbf{3 6 . 7 8 \%}$ & \\
\hline
\end{tabular}

Note. The Dual Class Premium [DCP] is calculated as the difference of stock prices of ON shares to PN shares divided by the price of ON shares. The table below displays descriptive statistics of annual DCP results from $1^{\text {st }}$ quarter 1995 to $4^{\text {th }}$ quarter 2006, including the mean, median, minimum and maximum value found within the yearly sample, as well as the standard deviation. For each year, last column displays the number of firms evaluated (\# of Firms).

According to Table 2, average dual class premium [DCP] diminished in Brazil from 1995 to 2000, starting to increase again after that date. Overall, we found a mean positive DCP of $7.68 \%$ for the whole period, with a median close to zero. DCP results for 1995-2002 are in line with those obtained by Saito (2003). However, the overall sample period mean and median are significantly higher. This is due to the inclusion of 2003-2006 data, a period where we found a positive and larger DCP. In addition, the evolution of DCP can be graphically seen in Figure 1. 


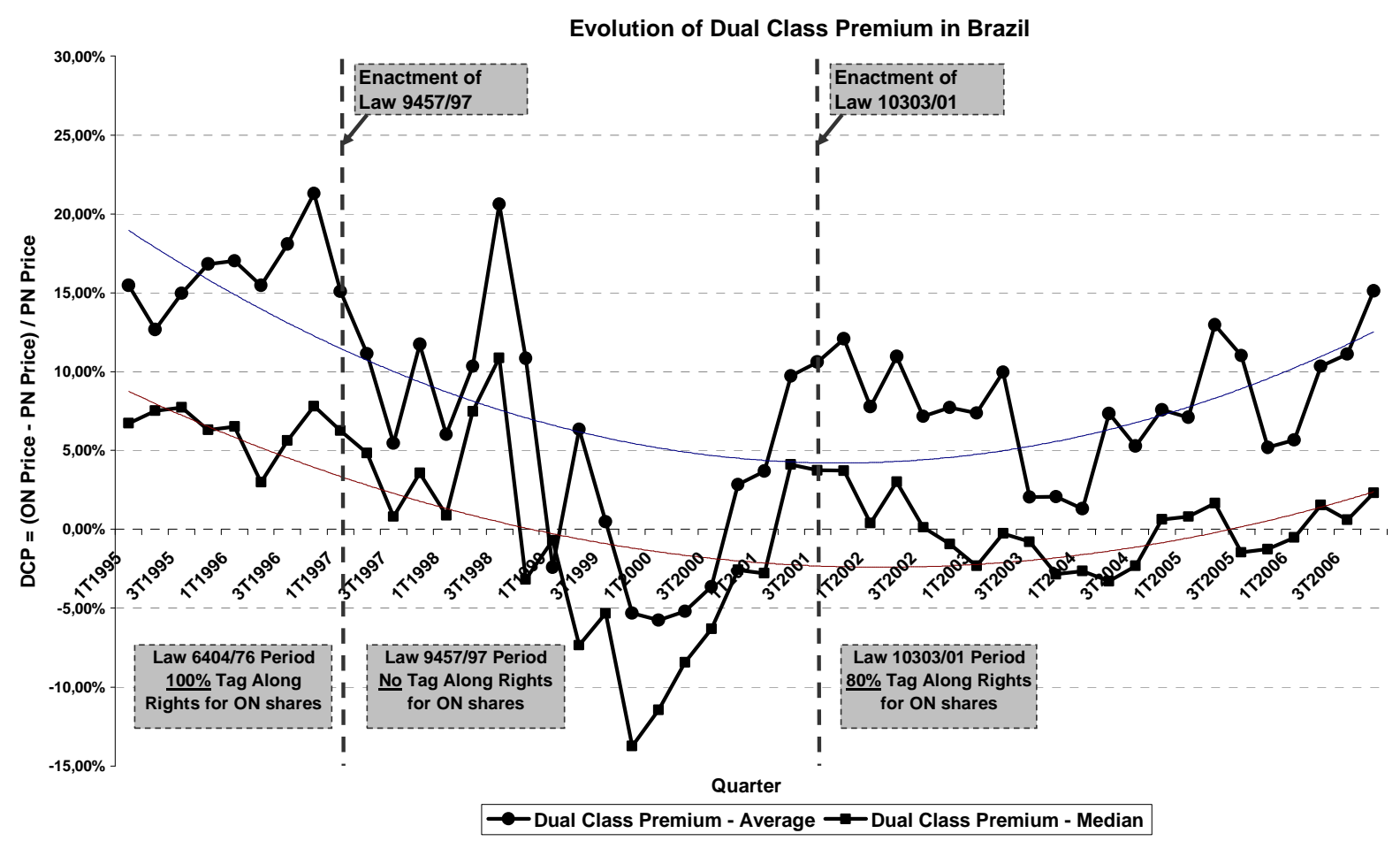

\begin{tabular}{lccc}
\cline { 2 - 4 } & Law 6404/76 & Law 9457/97 & Law 10303/01 \\
\cline { 2 - 4 } Mean & $16,4 \%$ & $4,1 \%$ & $8,0 \%$ \\
Median & $6,3 \%$ & $-2,1 \%$ & $-0,2 \%$ \\
Standard Dev & $38,6 \%$ & $39,7 \%$ & $34,1 \%$ \\
N (observ) & 377 & 1134 & 1775
\end{tabular}

\section{Test of differences between two-sample mean}

Ho: mean $($ Law 6404/76) - mean $(9457 / 97)=\operatorname{diff}=0$

Ha: diff $<0$ or Ha: diff $>0$

$\mathrm{T}=5.2625(\mathrm{P}<\mathrm{t}=1.0000)$

$P[$ diff mean $($ Law 6404/76) $-\operatorname{mean}(9457 / 97)<0]=1.0000$

Ho: mean $($ Law 9457/97) - mean $(10303 / 01)=\operatorname{diff}=0$

Ha: diff $<0$ or Ha: diff $>0$

$\mathrm{T}=2.8152(\mathrm{P}<\mathrm{t}=0.9975)$

$P[\operatorname{diff} \operatorname{mean}(\operatorname{Law} 9457 / 97)-\operatorname{mean}(10303 / 01)<0]=0.9975$

Figure 1: Evolution of Dual Class Premium in Brazil and Relation with Corporate Laws

The figure presents the evolution of the Dual Class Premium [DCP] in Brazil from 1995 to 2006. DCP is calculated as the difference ON shares stock prices to PN shares divided by the price of ON shares. The Chart depicts the yearly mean and median results obtained for the sample. Below the Chart, is a Table comparing the mean and median DCP results in three different sub-periods: before the enactment of Law 6.404/76, between the enactment of Law 6.404/76 and Law 10.303/01, and after the enactment of Law 10.303/01. Subsequently, tests of differences between two-sample means are displayed in order to compare mean results for the abovementioned three sub-periods. 
Figure 1 shows that the decrease and then increase of DCP in Brazil throughout the period can be reasonably proxied by a positive quadratic curve (trend lines on the chart for mean and median values). The chart also displays the two legal landmarks of the period: enactment of Laws 9.457/1997 and 10.303/2001. As a result, we can visually analyze the three distinct legal sub-periods. The chart shows that mean and median DCP for the three sub-periods comprised by the three laws in force from 1994 to 2006 are significantly different. Specifically, DCP is statistically larger during Law $6.404 / 1976$ (mean of $16.04 \%$ and median of 6.3\%) than during Law 9.457/1997 (mean of $4.1 \%$ and median of $-2.1 \%$ ), and is larger during Law 10303/01 (mean of $8.0 \%$ and median of $-0.2 \%$ ) than during the previous Law 9.457/1997 period. Both results are consistent with the predictions based on tag along rights granted for voting shares (100\% under Law 6.404/1976, 0\% under Law 9.457/1997, and $80 \%$ and Law 10.303/2001), which changed the relative advantage of voting shares vis-à-vis nonvoting shares. Moreover, we also found a larger DCP during Law 6.404/1976 than during Law $10.303 / 2001$. This result can occur due to two reasons: i) the larger relative advantage of voting shares during Law 6.404/1976 than during Law 10.303/2001 (100\% of tag along rights for ON shares in the former, against only $80 \%$ in the latter); or ii) the recent improvements in corporate governance quality in Brazil since 2000, resulting in smaller levels of private benefits of control and, consequently, in smaller DCP ${ }^{(20)}$.

Besides DCP evolution, we present descriptive statistics of selected explanatory variables in Table 3.

Table 3

\section{Descriptive Statistics for Selected Explanatory Variables}

\begin{tabular}{cccccccc}
\hline Variable & Unit & Mean & Median & Minimum & Maximum & $\begin{array}{c}\text { Std. } \\
\text { Deviation }\end{array}$ & $\begin{array}{c}\# \text { of } \\
\text { Observ. }\end{array}$ \\
\hline Total Assets & R\$’000 & $13,030,081$ & $1,958,992$ & 11,783 & $245,925,353$ & $33,271,004$ & 3,254 \\
Revenues & R\$’000 & $2,672,049$ & 627,572 & 86,41 & $140,896,903$ & $8,118,432$ & 2,730 \\
ON_conc & $\%$ & 56.0 & 52.3 & 7.7 & 100.0 & 24.9 & 3,286 \\
TS_conc & $\%$ & 52.1 & 49.1 & 7.7 & 100.0 & 24.4 & 3,284 \\
RAT_ON & $\%$ & 48.0 & 46.0 & 32.6 & 98.3 & 15.9 & 3,286 \\
Lever & $\%$ & 59.7 & 59.6 & 0.01 & 386.2 & 32.8 & 3,251 \\
LIQ_vol & & -2.49 & -2.43 & -13.72 & 9.84 & 2.96 & 2,960 \\
LIQ_neg & & -3.09 & -2.73 & -15.95 & 12.11 & 3.72 & 2,961 \\
DIV_DIF & & -0.86 & 0 & -1.00 & 0 & 0.21 & 3,285 \\
\hline
\end{tabular}

Note. The table provides descriptive statistics for relevant explanatory variables. Total assets and revenues are alternative measures of a firm's size, indicating total balance sheet assets and operational revenues, respectively. ON_conc and TS_conc are the percentage of voting $(\mathrm{ON})$ and total shares held by three largest shareholders. RAT_ON is the ratio of voting shares to the company's total outstanding shares. Lever is a measure of financial leverage of the companies. LIQ_vol and LIQ_neg are measures of the liquidity difference between ON and PN share classes, and DIV_DIF is a measure of the difference on dividends paid by voting $(\mathrm{ON})$ shares against non-voting $(\mathrm{PN})$ shares. A detailed description of all variables, including their operational definition, is presented in Table 2.

Table 3 shows four important characteristics of Brazilian corporate governance: i) a high degree of ownership concentration (overall mean of $56 \%$ of voting shares directly held by controlling shareholders); ii) a low ratio of voting shares to total outstanding shares (mean of $48 \%$ of total capital issued in the form of voting shares); iii) a larger share liquidity for non-voting shares; and, iv) larger dividends paid to non-voting shares against voting shares.

In order to initially analyze the association between DCP and the main explanatory variables, Table 4 presents a matrix correlation of selected variables. 
Table 4

Correlation Matrix between DCP and Selected Explanatory Variables

\begin{tabular}{cccccccccccc}
\hline & DCP & $\begin{array}{c}\text { LIQ_ } \\
\text { vol }\end{array}$ & $\begin{array}{c}\text { DIV_ } \\
\text { DIF }\end{array}$ & $\begin{array}{c}\text { DUM } \\
\text { DIV }\end{array}$ & InTA & $\begin{array}{c}\text { ON__ } \\
\text { conc }\end{array}$ & $\begin{array}{c}\text { TS_ } \\
\text { conc }\end{array}$ & $\begin{array}{c}\text { Taq_ } \\
\text { onpn }\end{array}$ & $\begin{array}{c}\text { Law } \\
6404\end{array}$ & $\begin{array}{c}\text { Law } \\
9457\end{array}$ & $\begin{array}{c}\text { Law } \\
10303\end{array}$ \\
\hline DCP & 1,00 & & & & & & & & & &
\end{tabular}

\begin{tabular}{|c|c|c|c|c|c|c|c|c|c|c|c|}
\hline \multirow[t]{2}{*}{ LIQ_vol } & 0.1030 & 1,00 & & & & & & & & & \\
\hline & 0.0000 & & & & & & & & & & \\
\hline \multirow[t]{2}{*}{ DIV_DIF } & -0.0433 & -0.0101 & 1,00 & & & & & & & & \\
\hline & 0.0206 & 0.5812 & & & & & & & & & \\
\hline \multirow[t]{2}{*}{ DUMIDV } & 0.0150 & 0.0128 & 0.2196 & 1,00 & & & & & & & \\
\hline & 0.4222 & 0.4850 & 0.0000 & & & & & & & & \\
\hline \multirow[t]{2}{*}{ InTA } & -0.0979 & -0.0243 & -0.1319 & -01008 & 1,00 & & & & & & \\
\hline & 0.0000 & 0.1888 & 0.0000 & 0.0000 & & & & & & & \\
\hline \multirow[t]{2}{*}{ ON_conc } & -0.0672 & 0.2407 & -0.0035 & 0.0975 & 0.0322 & 1,00 & & & & & \\
\hline & 0.0003 & 0.0000 & 0.8405 & 0.0000 & 0.0662 & & & & & & \\
\hline \multirow{2}{*}{ TS_conc } & -0.0620 & 0.3040 & -0.0256 & 0.0777 & -0.0025 & 0.9032 & 1,00 & & & & \\
\hline & 0.0009 & 0.0000 & 01430 & 0.0000 & 0.8848 & 0.0000 & & & & & \\
\hline \multirow[t]{2}{*}{ Taq_onpn } & -0.0934 & -0.2264 & 0.0302 & -0.0079 & 0.1550 & -01331 & -0.1046 & 1,00 & & & \\
\hline & 0.0000 & 0.0000 & 0.0831 & 0.6495 & 0.0000 & 0.0000 & 0.0000 & & & & \\
\hline \multirow[t]{2}{*}{$\begin{array}{l}\text { Law } \\
6404\end{array}$} & 0.1024 & 0.0104 & 0.0593 & 0.0947 & 0.0679 & 0.1764 & -0.1019 & -0.0686 & 1,00 & & \\
\hline & 0.0000 & 05716 & 0.0007 & 0.0000 & 0.0001 & 0.0000 & 0.0000 & 0.0001 & & & \\
\hline \multirow[t]{2}{*}{$\begin{array}{l}\text { Law } \\
9457\end{array}$} & -0.0845 & 0.0165 & -0.0376 & -0.0078 & 0.0364 & -0.0476 & -0.0436 & -0.1382 & -02613 & 1,00 & \\
\hline & 0.0000 & 0.3686 & 0.0311 & 0.6553 & 0.0380 & 0.0064 & 0.0124 & 0.0000 & 0.0000 & & \\
\hline \multirow[t]{2}{*}{$\begin{array}{l}\text { Law } \\
10303\end{array}$} & 0.0130 & -0.0225 & -0.0021 & -0.0531 & -0.0777 & -0.0674 & 0.1086 & 0.1757 & -0.3902 & -0.7868 & 1,00 \\
\hline & 0.4870 & 0.2211 & 0.9054 & 0.0023 & 0.0000 & 0.0001 & 0.0000 & 0.0000 & 0.0000 & 0.0000 & \\
\hline
\end{tabular}

Note. The table displays the correlation matrix between the main variables of the study. DCP is the Dual Class Premium, calculated as the difference of stock prices of ON shares to PN shares divided by the price of ON shares. LIQ_vol and LIQ_neg are measures of the liquidity difference between ON and PN share classes. DIV_DIF is a measure of the difference on dividends paid by voting (ON) shares against non-voting (PN) shares. DUM_DIV is a dummy variable indicating if ON shares received the same or superior dividends regarding PN shares. $\operatorname{lnTA}$ is the natural logarithm of total accounting assets. ON_conc and TS_conc are the percentage of voting $(\mathrm{ON})$ and total shares held by three largest shareholders. Tag_onpn. Tag_onpn is a dummy variable indicating whether the firm voluntarily grants tag along rights both for ON and PN shares. Law 6404, Law 9457, and Law 10303 are dummy variables assuming a value equal to 1 for the three different sub-periods under analysis (before the enactment of Law 6.404/76, between the enactment of Law 6.404/76 and Law 10.303/01, and after the enactment of Law 10.303/01), and zero otherwise. A detailed description of all variables, including their operational definition, is presented in Table 2. 
Table 4 shows statistically significant (at $1 \%$ level) correlations of several explanatory variables with DCP in line with our hypothesis: i) the voluntarily granting of tag along rights negatively correlated with DCP; ii) Law 6.404/1976 and Law 9.457/1997 dummies positively and negatively related with DCP, respectively; iii) larger liquidity of voting shares vis-à-vis non-voting positively associated with larger DCP; iv) firm size negatively correlated with DCP; and, v) the concentration of voting rights and cash flow rights held by controlling shareholders negatively correlated with DCP.

\section{Determinants of Dual-class Share Premium}

In order to analyze the potential determinants of DCP in Brazil, we performed pooled OLS regressions and Fixed Effects [FE] procedures. The results from eight different model specifications performed with OLS and FE are presented in Tables 5 and 6, respectively.

Table 5

Determinants of Dual Class Premium [DCP] in Brazil - OLS Regressions

\begin{tabular}{|c|c|c|c|c|c|c|c|c|}
\hline & \multicolumn{8}{|c|}{ Dual class premium [DCP] } \\
\hline & (1) & (2) & (3) & (4) & (5) & (6) & (7) & (8) \\
\hline LIQ_vol & $\begin{array}{c}0.011^{* * *} \\
(4.19)\end{array}$ & & $\begin{array}{c}0.009^{* * * *} \\
(3.14)\end{array}$ & $\begin{array}{c}0.008^{* * * *} \\
(2.94)\end{array}$ & $\begin{array}{c}0.008^{* * * *} \\
(2.79)\end{array}$ & $\begin{array}{c}0.012^{* * * *} \\
(4.33)\end{array}$ & $\begin{array}{c}0.008 * * * \\
(2.69)\end{array}$ & $\begin{array}{c}0.007^{* *} \\
(2.41)\end{array}$ \\
\hline LIQ_neg & & $\begin{array}{c}0.004 * \\
(1.93)\end{array}$ & & & & & & \\
\hline DIV_DIF & $\begin{array}{l}0.001 \\
(0.25)\end{array}$ & & & $\begin{array}{l}-0.014 \\
(-0.43)\end{array}$ & & $\begin{array}{l}-0.006 \\
(-0.20)\end{array}$ & $\begin{array}{l}-0.002 \\
(-0.07)\end{array}$ & \\
\hline DUM_DIV & & $\begin{array}{l}-0.004 \\
(-0.29)\end{array}$ & $\begin{array}{l}-0.007 \\
(-0.47)\end{array}$ & & $\begin{array}{l}-0.001 \\
(0.11)\end{array}$ & & & $\begin{array}{l}-0.017 \\
(-1.09)\end{array}$ \\
\hline ON_conc & & & $\begin{array}{c}0.001 * \\
(1.78)\end{array}$ & $\begin{array}{c}- \\
0.001 * * * \\
(-4.42)\end{array}$ & $\begin{array}{c}-0.001 * * \\
(-2.11)\end{array}$ & & $\begin{array}{c}- \\
0.001 * * * \\
(-4.40)\end{array}$ & $\begin{array}{c}- \\
0.002^{* * *} \\
(-3.63)\end{array}$ \\
\hline TS_conc & & & $\begin{array}{c}- \\
0.002^{-} * * * \\
(-3.45)\end{array}$ & & & $\begin{array}{c}- \\
0.001^{* * * *} \\
(-3.42)\end{array}$ & & $\begin{array}{c}0.001 * \\
(1.92)\end{array}$ \\
\hline RAT_ON & & & $\begin{array}{c}0.199 * * * \\
(4.09)\end{array}$ & $\begin{array}{c}0.190 * * * \\
(4.02)\end{array}$ & $\begin{array}{c}0.165^{* * * *} \\
(3.47)\end{array}$ & & $\begin{array}{c}0.173 * * * \\
(3.67)\end{array}$ & $\begin{array}{c}0.171 * * * \\
(3.55)\end{array}$ \\
\hline $\ln T A$ & $\begin{array}{c}- \\
0.026 * * * \\
(-6.45)\end{array}$ & $\begin{array}{c}- \\
0.028 * * * \\
(-7.06)\end{array}$ & $\begin{array}{c}- \\
0.032^{* * * *} \\
(-7.55)\end{array}$ & $\begin{array}{c}- \\
0.033^{*} * * \\
(-7.98)\end{array}$ & $\begin{array}{c}- \\
0.028 * * * \\
(-6.87)\end{array}$ & $\begin{array}{c}- \\
0.029 * * * \\
(-6.80)\end{array}$ & $\begin{array}{c}- \\
0.029 * * * \\
(-6.80)\end{array}$ & $\begin{array}{c}- \\
0.030^{* * *} \\
(-6.95)\end{array}$ \\
\hline LEVER & & & $\begin{array}{c}0.001 * * * \\
(2.59)\end{array}$ & $\begin{array}{c}0.001 * * * \\
(3.17)\end{array}$ & $\begin{array}{c}0.001 * \\
(1.79)\end{array}$ & $\begin{array}{l}0.001 \\
(1.29)\end{array}$ & & $\begin{array}{c}0.001 * * * \\
(2.95)\end{array}$ \\
\hline LEVER_quad & & & $\begin{array}{c}- \\
0.001 * * * \\
(-2.90)\end{array}$ & $\begin{array}{c}- \\
0.001 * * * \\
(-3.36)\end{array}$ & $\begin{array}{c}-0.001 * * \\
(-2.37)\end{array}$ & $\begin{array}{c}-0.001 * * \\
(-2.04)\end{array}$ & & $\begin{array}{c}- \\
0.001 * * * \\
(-3.24)\end{array}$ \\
\hline
\end{tabular}


Table 5 (continued)

Dual class premium [DCP]

\begin{tabular}{|c|c|c|c|c|c|c|c|c|}
\hline & (1) & (2) & (3) & (4) & (5) & (6) & (7) & (8) \\
\hline Law 6404 & & & & $\begin{array}{c}0.186^{* * * *} \\
(8.21)\end{array}$ & & & $\begin{array}{c}0.178 * * * \\
(7.93)\end{array}$ & $\begin{array}{c}0.182^{* * * *} \\
(6.41)\end{array}$ \\
\hline Law 9457 & & & & & & $\begin{array}{c}- \\
0.068^{* * *} \\
(-5.15)\end{array}$ & & $\begin{array}{c}-0.032 * * \\
(-2.30)\end{array}$ \\
\hline Law 10303 & & & & $\begin{array}{c}0.031 * * \\
(2.41)\end{array}$ & & & $\begin{array}{c}0.047 * * * \\
(3.54)\end{array}$ & \\
\hline Tag_pn & & & & & $\begin{array}{l}-0.031 \\
(-1.41)\end{array}$ & & & \\
\hline Tag_onpn & & & & & & $\begin{array}{c}- \\
0.080^{* * * *} \\
(-4.41)\end{array}$ & & \\
\hline Tag_Along & & & & & & & $\begin{array}{c}-0.043 * * \\
(-2.41)\end{array}$ & $\begin{array}{c}-0.042^{* *} \\
(-2.36)\end{array}$ \\
\hline FAM & $\begin{array}{c}0.066^{* * *} \\
(2.53)\end{array}$ & $\begin{array}{c}0.056^{* *} \\
(2.14)\end{array}$ & $\begin{array}{c}0.064 * * \\
(2.45)\end{array}$ & $\begin{array}{c}0.061 * * \\
(2.33)\end{array}$ & $\begin{array}{c}0.074 * * * \\
(2.74)\end{array}$ & $\begin{array}{c}0.051^{* *} \\
(1.93)\end{array}$ & $\begin{array}{c}0.068 * * \\
(2.54)\end{array}$ & $\begin{array}{c}0.070 * * * \\
(2.62)\end{array}$ \\
\hline SOE & $\begin{array}{l}0.000 \\
(0.02)\end{array}$ & $\begin{array}{l}-0.003 \\
(-0.12)\end{array}$ & $\begin{array}{l}0.011 \\
(0.43)\end{array}$ & $\begin{array}{l}0.011 \\
(0.45)\end{array}$ & $\begin{array}{l}0.015 \\
(0.58)\end{array}$ & $\begin{array}{l}-0.010 \\
(-0.40)\end{array}$ & $\begin{array}{l}0.011 \\
(0.44)\end{array}$ & $\begin{array}{l}0.012 \\
(0.46)\end{array}$ \\
\hline
\end{tabular}

\begin{tabular}{lcccccccc} 
Dummies & YES & YES & YES & YES & YES & YES & YES & YES \\
Industry & & & & & & & & \\
Intercept & $0.287 * * *$ & $0.567 * * *$ & $0.266 * * *$ & $0.527 * * *$ & $0.213^{* * *}$ & $0.662^{* * *}$ & $0.273 * * *$ & $0.272 * * *$ \\
$\mathbf{R}^{2}$ & $(4.09)$ & $(7.69)$ & $(3.09)$ & $(6.33)$ & $(2.47)$ & $(8.37)$ & $(3.09)$ & $(3.19)$ \\
Prob. (F) & 0.13 & 0.12 & 0.14 & 0.16 & 0.13 & 0.14 & 0.16 & 0.16 \\
Firms (n) & 0.000 & 0.000 & 0.000 & 0.000 & 0.000 & 0.000 & 0.000 & 0.000 \\
\hline
\end{tabular}

Note. The Dual Class Premium [DCP] is the dependent variable. DCP is calculated as the difference of stock prices of ON shares to PN shares divided by the price of ON shares. A detailed description of DCP, along with operational definition of all explanatory variables is presented in Table 2. Binary variables related to the firms' industry (IND) were included in the regressions below, being omitted from the tables for reasons of space. The sample is comprised of 2,590 firm-years observations for the 1995-2006 period. Figures in parentheses indicate the $t$ statistics. ***, **, and * correspond to statistical significance at $1 \%, 5 \%$, and $10 \%$ respectively. The coefficients were estimated through the Ordinary Least Squares method [OLS] with heterocedasticity-robust standard errors. 
Table 6

Determinants of Dual Class Premium [DCP] in Brazil - Fixed-Effects Regressions

\begin{tabular}{|c|c|c|c|c|c|c|c|c|}
\hline & \multicolumn{8}{|c|}{ Dual class premium [DCP] } \\
\hline & (1) & (2) & (3) & (4) & (5) & (6) & (7) & (8) \\
\hline LIQ_vol & $\begin{array}{c}0.010 * * * \\
(3.01)\end{array}$ & & $\begin{array}{c}0.009 * * * \\
(2.89)\end{array}$ & $\begin{array}{c}0.008 * * * \\
(2.75)\end{array}$ & $\begin{array}{c}0.009 * * * \\
(2.97)\end{array}$ & $\begin{array}{c}0.010 * * * \\
(3.17)\end{array}$ & $\begin{array}{c}0.008 * * * \\
(2.71)\end{array}$ & $\begin{array}{c}0.009 * * * \\
(2.76)\end{array}$ \\
\hline LIQ_neg & & $\begin{array}{l}0.004 \\
(1.27)\end{array}$ & & & & & & \\
\hline DIV_DIF & $\begin{array}{c}0.085^{* * * *} \\
(3.16)\end{array}$ & & & $\begin{array}{c}0.055^{* *} * \\
(2.07)\end{array}$ & & $\begin{array}{c}0.059 * * \\
(2.22)\end{array}$ & $\begin{array}{c}0.057 * * \\
(2.19)\end{array}$ & \\
\hline DUM_DIV & & $\begin{array}{l}0.017 \\
(1.17)\end{array}$ & $\begin{array}{l}0.003 \\
(0.17)\end{array}$ & & $\begin{array}{l}0.016 \\
(1.09)\end{array}$ & & & $\begin{array}{l}-0.003 \\
(-0.19)\end{array}$ \\
\hline ON_conc & & & $\begin{array}{c}0.002 * * * \\
(3.34)\end{array}$ & $\begin{array}{c}-0.002 * * * \\
(-5.46)\end{array}$ & $\begin{array}{c}-0.001 * * \\
(-2.00)\end{array}$ & & $\begin{array}{c}-0.002 * * * \\
(-5.68)\end{array}$ & $\begin{array}{l}-0.001 \\
(-0.49)\end{array}$ \\
\hline TS_conc & & & $\begin{array}{c}-0.005 * * * \\
(-8.18)\end{array}$ & & & $\begin{array}{c}-0.004 * * * \\
(-7.88)\end{array}$ & & $\begin{array}{c}-0.004 * * * \\
(4.66)\end{array}$ \\
\hline RAT_ON & & & $\begin{array}{c}0.579 * * * \\
\quad(5.03)\end{array}$ & $\begin{array}{c}0.381 * * * \\
(3.42)\end{array}$ & $\begin{array}{c}0.387 * * * \\
(3.39)\end{array}$ & & $\begin{array}{c}0.385^{* * *} * \\
(3.46)\end{array}$ & $\begin{array}{c}0.530 * * * \\
(4.61)\end{array}$ \\
\hline $\ln \mathrm{TA}$ & $\begin{array}{l}-0.014 \\
(-1.20)\end{array}$ & $\begin{array}{l}-0.013 \\
(-1.10)\end{array}$ & $\begin{array}{l}-0.014 \\
(-0.97)\end{array}$ & $\begin{array}{l}-0.017 \\
(-1.17)\end{array}$ & $\begin{array}{l}-0.017 \\
(-1.17)\end{array}$ & $\begin{array}{l}-0.016 \\
(-1.11)\end{array}$ & $\begin{array}{l}-0.007 \\
(-0.53)\end{array}$ & $\begin{array}{l}-0.009 \\
(-0.64)\end{array}$ \\
\hline LEVER & & & $\begin{array}{l}0.001 \\
(0.84)\end{array}$ & $\begin{array}{l}0.001 \\
(0.39)\end{array}$ & $\begin{array}{l}0.001 \\
(0.10)\end{array}$ & $\begin{array}{l}-0.001 \\
(-0.55)\end{array}$ & & $\begin{array}{l}0.001 \\
(0.27)\end{array}$ \\
\hline LEVER_quad & & & $\begin{array}{l}0.000 \\
(0.37)\end{array}$ & $\begin{array}{l}0.000 \\
(0.24)\end{array}$ & $\begin{array}{l}0.001 \\
(0.32)\end{array}$ & $\begin{array}{l}0.001 \\
(0.58)\end{array}$ & & $\begin{array}{l}0.001 \\
(0.41)\end{array}$ \\
\hline Law 6404 & & & & $\begin{array}{c}0.187 * * * \\
(10.42)\end{array}$ & & & $\begin{array}{c}0.188^{* * * *} \\
(10.42)\end{array}$ & $\begin{array}{c}0.078 * * * \\
(3.38)\end{array}$ \\
\hline Law 9457 & & & & & & $\begin{array}{c}-0.083 * * * \\
(-7.43)\end{array}$ & & $\begin{array}{c}-0.065 * * \\
(-4.99)\end{array}$ \\
\hline Law 10303 & & & & $\begin{array}{c}0.043 * * * \\
(3.62)\end{array}$ & & & $\begin{array}{c}0.051^{* * * *} \\
(4.23)\end{array}$ & \\
\hline Tag_pn & & & & & $\begin{array}{l}-0.041 \\
(-1.33)\end{array}$ & & & \\
\hline Tag_onpn & & & & & & $\begin{array}{l}-0.019 \\
(-0.57)\end{array}$ & & \\
\hline Tag_Along & & & & & & & $\begin{array}{l}-0.026 \\
(-1.04)\end{array}$ & $\begin{array}{l}-0.032 \\
(-1.27)\end{array}$ \\
\hline $\begin{array}{l}\text { Dummies } \\
\text { Industry }\end{array}$ & NO & $\mathrm{NO}$ & $\mathrm{NO}$ & NO & $\mathrm{NO}$ & NO & NO & NO \\
\hline Intercept & $\begin{array}{c}0.311 * \\
(1.79)\end{array}$ & $\begin{array}{c}0.258 * \\
(1.47)\end{array}$ & $\begin{array}{l}0.159 \\
(0.76)\end{array}$ & $\begin{array}{l}0.225 \\
(1.08)\end{array}$ & $\begin{array}{l}0.190 \\
(0.88)\end{array}$ & $\begin{array}{c}0.593 * * * \\
(2.90)\end{array}$ & $\begin{array}{l}0.095 \\
(0.49)\end{array}$ & $\begin{array}{l}0.187 \\
(0.86)\end{array}$ \\
\hline $\mathbf{R}^{2}$ within & 0.01 & 0.01 & 0.03 & 0.05 & 0.01 & 0.05 & 0.05 & 0.06 \\
\hline Prob. (F) & 0.000 & 0.000 & 0.000 & 0.000 & 0.000 & 0.000 & 0.000 & 0.000 \\
\hline Obs. (n) & 2,637 & 2,639 & 2,633 & 2,634 & 2,635 & 2,632 & 2,637 & 2,633 \\
\hline
\end{tabular}

Note. The Dual Class Premium [DCP] is the dependent variable. DCP is calculated as the difference of stock prices of ON shares to PN shares divided by the price of ON shares. A detailed description of DCP, along with operational definition of all explanatory variables, is presented in Table 2. The sample is comprised of 2,590 firm-years observations for the 1995-2006 period. Figures in parentheses indicate the $t$ statistics. $* * * * *$, and $*$ correspond to statistical significance at $1 \%, 5 \%$, and $10 \%$ respectively. The coefficients were estimated through the Fixed-Effects procedure [FE]. 
Taking into account both OLS and FE regressions (particularly the results from FE procedure, considered more robust ${ }^{(21)}$ ), we observed the following results (all of them in line with the hypotheses): 1) The influence of the enactment of corporate laws on DCP: a positive association between Laws 6.404/1976 and 10.303/2001 dummies and DCP, and a negative association between Law 9.457/1997 dummy and DCP; 2) Family control positively associated with DCP; 3) A larger relative liquidity of voting shares positively associated with DCP; 4) A larger relative amount of dividends paid to voting shares positively associated with DCP; 5) The percentage of voting shares (control rights) held by controlling shareholders negatively associated with DCP; 6) The percentage of total shares (cash flow rights) held by controlling shareholders negatively associated with DCP; 7) The ratio of voting shares to total shares positively associated with DCP.

For the remaining variables (firms' size, financial leverage, and voluntary granting of tag along rights), we did not find a significant result after performing FE regressions. Therefore, we prefer not to be conclusive on these variables due to the potential econometric problems that could arise in OLS regressions. Results with the voluntary granting of tag along rights can be considered intriguing. We hypothesized a negative impact on DCP when firms voluntarily grant this mandatory bid rules for both share classes (simultaneously raising the tag along of voting shares from $80 \%$ to $100 \%$ and the tag along for non-voting shares from $0 \%$ to $80 \%$ or above), or when they grant these tag along rights only to non-voting shares, since in both cases a potential relative advantage of voting shares would be taken off. Although we found a negative sign for the coefficients of tag along rights' variables in all specifications, we did not observe statistical significance in FE regressions. This result could have occurred for at least one of two reasons: i) as explained in the previous section describing the institutional framework in Brazil, firms can choose to provide non-voting shares one of three advantages determined by Law 10.303/2001. Since tag along rights is one of these advantages, some firms could have exchanged the extra benefit for non-voting shares (for instance, canceling their additional dividends when they grant tag along rights). Therefore, the net relative gain for non-voting shares would not be significant when firms voluntarily grant tag along rights, leading to a null impact on DCP; and/or, ii) the voluntarily granting of tag along rights started only after 2001, which could have led to insignificant coefficients due to few observations in our sample.

Overall, our results strongly support the following hypotheses of our study: H1 and H2 - exogenous changes on Corporate Law do influence the relative value of one share class against the other one; H4 - the presence of a family as a controlling shareholders tends to increase the DCP, probably due to larger private benefits of control taking place; $\mathrm{H6}$ - a higher relative payment of dividends to nonvoting shares negatively influences DCP; H7 - a higher relative liquidity of voting shares tends to increase DCP; H8 - companies with a higher ratio of voting shares against all outstanding shares tend to increase the relative value of voting shares, thus enhancing DCP; H9 - a higher percentage of voting shares held by controlling shareholders tends to reduce DCP, probably due to a lower probability of takeover contests.

On the other hand, our results do not offer conclusive support for the hypotheses that: $\mathrm{H} 3$-the voluntary granting of tag along rights negatively influences DCP; H5 - state-owned control reduces DCP; H10 - there is a quadratic relationship between financial leverage and DCP; and, H11 - a firm's size negatively influences the level of DCP.

\section{CONCLUDING REMARKS}

This paper aimed to analyze the evolution and potential determinants of the so-called dual class premium in Brazil from 1995 to 2006 with a focus on two specific corporate governance aspects: the granting of tag along rights, and the identity of the controlling shareholders. We consider Brazil an interesting case since listed firms have: widespread issuance of non-voting shares; significant presence of family control; and, have been under significant legal and voluntary changes throughout this period which changed the level of tag along rights of one share class against the other one. 
Two main results stand out. Firstly, we observed a significant influence of the enactment of two different corporate laws on DCP. Specifically, exogenous legal changes regarding tag along rights that increased (decreased) the relative advantage of voting shares increased (decreased) DCP in Brazil. Secondly, we find a positive relation between family control and DCP in all specifications. Our first main result is in line with results obtained by Silva and Subrahmanyam (2007) in Brazil, whereas our second is in line with results obtained by Caprio and Croci (2008) in Italy. However, unlike the previous paper recently conducted in Brazil, we did not find robust evidence that voluntary granting of tag along rights (an endogenous choice by firms willing to display higher corporate governance standards) influenced DCP level in our sample. The disparity of the results may be due to the different methodological approaches employed. Whereas Silva and Subrahmanyam (2007) investigated the impact of tag along rights on DCP by an event study analysis, we investigated the same phenomenon by panel data techniques.

Besides the two main results, we found three other important results: i) unlike other papers in this line of research that have found relatively stable levels for DCP in their countries, we found a significant variation in DCP in Brazil during our sample period, ranging from a mean (median) of $17.97 \%$ (4.95\%) in 1996 to $-2.87 \%(-6.93 \%)$ in 2000; ii) higher share liquidity and dividend yields for non-voting shares are negatively associated with DCP; and, iii) the concentration of both control rights and cash flow rights by controlling shareholders are negatively associated with DCP level.

Overall, our paper contributes to this line of research in terms of: i) scope - the inclusion of the identity of controlling shareholders as an explanatory factor of DCP); ii) methodology - analysis of recent data collected for a long time span by panel data techniques; and, iii) results - positive influence of family control on DCP and different results regarding the voluntary granting of tag along rights.

As policy implications, our results show that regulations regarding shareholders' rights and the identity of controlling shareholders are two crucial corporate governance variables for the level of DCP in environments characterized by concentrated ownership structures and the prevalence of agency problems between controlling and minority shareholders.

\section{NOTES}

\footnotetext{
${ }^{1}$ Based on the well accepted premise that the value of a financial asset is given by the present value of its future cash flows discounted by its appropriate opportunity cost of capital.

${ }^{2}$ The theoretical arguments for the relationship between different equity classes are shown in Grossmann, S., \& Hart, O. (1988). One share-one vote and the market for corporate control. Journal of Financial Economics, 20, 175-202, and Harris, M., \& Raviv, A. (1988). Corporate governance, voting rights and majority rules. Journal of Financial Economics, 20(2), 203235. The models presented in both papers are derived from takeover stories, predicting a premium for stocks with superior voting rights. On the empirical side, several studies since the early 80 s have analyzed the value of voting rights. As examples of such studies, Lease et al. (1983), Megginson, W. L. (1990). Restricted voting stock, acquisition premiums, and the market value of corporate control. The Financial Review, 25(2), 175-198, Zingales, L. (1994). The value of the voting rights: a study of the Milan stock exchange. Review of Financial Studies, 7(1), 1047-1073. Zingales, L. (1995). What determines the value of corporate votes? Quarterly Journal of Economics, 110(4), 1047-1073 and Cox, S., \& Roden, D. (2002). The source of value of voting rights and related dividend promises. Journal of Corporate Finance, 8(4), 337-351, provide evidence for the US market; Smith, B., \& Amoako-Adu, B. (1995). Relative prices of dual class shares. Journal of Financial and Quantitative Analysis, 30(2), 223-239, for Canada; Levy, H. (1983). Economics evaluation of voting power of common stock. Journal of Finance, 38(1), 79-93, for Israel; Zingales (1994), Linciano (2003) and Caprio and Croci (2008), for Italy, Bergström, C., \& Rydqvist, K. (1990). Ownership of equity in dual class firms. Journal of Banking and Finance, 14(2-3), 255-269 and Rydqvist, K. (1996). Takeover bids and the relative prices of shares that differ in their voting rights. Journal of Banking and Finance, 20(8), 1407-1425, for Sweden; Neumann, R. (2003). Price differentials between dual-class stocks: voting premium or liquidity discount. European Financial Management, 9(3), 315-332, for Denmark; and Ødegaard (2006) for Norway. Nenova (2003) presented the first cross-country analysis on this field of research. As an overall result (with the exception of Neumann (2003) and the partial exception of Ødegaard (2006), these papers have found that shares with superior voting rights really do trade at a premium.
}

\footnotetext{
${ }^{3}$ Damodaran (2005, p. 50) states that "the shares that carry no or fewer voting rights should be worth less than shares that carry more voting power and the difference in price should be a function of the expected value of control. The premium on
} 
voting shares should therefore be a function of the probability that there will be a change in management at that firm and the value of changing management".

${ }^{4}$ Listed companies in Brazil historically have a controlling shareholder or a controlling group (usually connected by a formal shareholder agreement) holding more than $50 \%$ of voting shares. Since 2005 , we have seen the emergence of a couple of widely held firms with no controlling shareholders, such as Lojas Renner (retail) and Embraer (aeronautic). However, these firms constitute the exception, and none of them are in our sample.

${ }^{5}$ For the U.S. market, Lease, R., McConnell, J., \& Mikkelson, W. (1983). The market value of control in publicly traded corporations. Journal of Financial Economics, 11(1/4), 439-471, found a relatively small premium of 5-10\% of voting over non-voting shares. Zingales (1995) confirmed their result, finding a premium of the same magnitude.

${ }^{6}$ Israel (46\%, Levy, 1982), Latin America (50-100\%) and Italy (80\%, Zingales, 1994).

${ }^{7}$ Silva and Subrahmanyam (2007) report a negative median dual-class premium for eight of the eleven years analyzed by them (1994-2004).

${ }^{8}$ The main rationale for this change was to facilitate the ongoing privatization program, allowing the Government to sell off its controlling stakes without sharing the control premium with minority shareholders.

${ }^{9}$ For instance, the migration to Bovespa's special listing segment Level 2 requires firms to grant tag along rights of $100 \%$ to minority voting shareholders and of $80 \%$ to non-voting shareholders. On October 4, 2007, 141 firms (about $32 \%$ of all firms listed at Bovespa) voluntarily granted tag along rights beyond the legal requirements.

${ }^{10}$ According to Nenova (2001, p. 2), the country boasts the world's widest average wedge between control and cash flow rights of listed companies and $89 \%$ of all listed companies have issued non-voting shares.

${ }^{11}$ In a recent paper with around 200 listed firms, Silveira, A. Di M. da, Leal, R. P. C., Silva, A. L. C. da, \& Barros, L. A. B. C. de (2007). Evolution and determinants of firm-level corporate governance quality in Brazil [Working Paper Series]. Social Science Research Network, New York, NY. Retrieved September 5, 2009, from http://ssrn.com/abstract=995764, found that in $2004,51 \%$ of Brazilian firms were controlled by families, $24.4 \%$ were controlled by a group of different investors, $17.5 \%$ were controlled by foreigners, and $6.6 \%$ were controlled by the government.

${ }^{12}$ The authors find that the presence of a family as the largest shareholder increases the voting premium.

${ }^{13}$ This requirement could not be applied to cases where the corporate charters specified the size and features of the dividend rights of non-voting shares.

${ }^{14}$ However, this rule only applies to new firms or for firms established before but decided to go public after October 2001.

15 The provisions of CVM Instruction 299/1999 reinstating minority shareholders rights were later incorporated into Law $10.303 / 2001$.

${ }^{16}$ For share prices, we compute the closing share price of the last day of the respective quarter. We use the financial statement available on the respective quarter for accounting and ownership variables. Therefore, the accounting (firms' size and leverage) and ownership variables (percentage of shares held by controlling shareholders) employed in a given quarter are referred to the immediately previous quarter.

${ }^{17}$ Economatica ${ }^{\circledR}$ is a database system focused on Latin American firms.

${ }^{18}$ We reran all analyses without winsorizing DCP. The results remain qualitatively the same. We thank an anonymous referee for this request.

${ }^{19}$ We also ran Randon Effects tests. After the comparison with Fixed Effects results by applying Hausman test, we decided to report only Fixed Effect results.

${ }^{20}$ Silveira et al. (2007) provide evidence of the improvement of overall corporate governance quality in Brazil from 2000 to 2006.

${ }^{21}$ Since the OLS method does not account for unobserved firm characteristics that could hinder the correct relationship identification between DCP and its potential determinants, we rely on the results from the FE method.

\section{REFERENCES}

Adams, R., \& Ferreira, D. (2007). One share, one vote: the empirical evidence [Working Paper $\mathrm{N}^{\circ}$ 177/2007]. European Corporate Governance Institute, Brussels, BE. Retrieved September 5, 2009, from http://ssrn.com/abstract=987488 
Caprio, L., \& Croci, E. (2008). The determinants of the voting premium in Italy: the evidence from 1974 to 2003. Journal of Banking and Finance, 32(11), 2433-2443.

Damodaran, A. (2005). The value of control: implications for control premia, minority discounts and voting shares differentials [Working Paper Series]. Stern School of Business, New York, NY. Retrieved September 5, 2009, from http://ssrn.com/abstract=837405

Doidge, C. (2004). U.S. cross-listings and the private benefits of control: evidence from dual-class firms. Journal of Financial Economics, 72(3), 519-553.

Dyck, A., \& Zingales, L. (2004). Private benefits of control: an international comparison. Journal of Finance, 59(2), 537-600.

Lei n. 6.404, de 15 de dezembro de 1976 (1976). Dispõe sobre as sociedades por ações. Diário Oficial da União. Brasília, DF: Ministério da Fazenda.

Lei n. 9.457, de 5 de maio de 1997 (1997). Altera dispositivos da Lei $\mathrm{n}^{\circ} 6.404$, de 15 de dezembro de 1976, que dispõe sobre as sociedades por ações e da Lei $n^{\circ}$ 6.385, de 7 de dezembro de 1976, que dispõe sobre o mercado de valores mobiliários e cria a Comissão de Valores Mobiliários. Diário Oficial da União. Brasília, DF: Ministério da Fazenda.

Lei n. 10.303, de 31 de outubro de 2001 (2001). Altera e acrescenta dispositivos na Lei no 6.404, de 15 de dezembro de 1976, que dispõe sobre as Sociedades por Ações, e na Lei no 6.385, de 7 de dezembro de 1976, que dispõe sobre o mercado de valores mobiliários e cria a Comissão de Valores Mobiliários. Diário Oficial da União. Brasília, DF: Ministério da Fazenda.

Linciano, N. (2003). Non-voting shares and the value of control: the impact of corporate regulation in Italy [Working Paper No 7203]. Social Science Research Network, New York, NY. Retrieved September 5, 2009, from http://ssrn.com/abstract=410191

Nenova, T. (2001). Control values and changes in corporate law in Brazil [Working Paper Series]. European Financial Management Association, London, England. Retrieved September 5, 2009, from http://ssrn.com/abstract=294064

Nenova, T. (2003). The value of corporate voting rights and control: a cross-country analysis. Journal of Financial Economics, 68(3), 325-351.

Ødegaard, B. (2006). Price differences between equity classes. Corporate control, foreign ownership or liquidity? [Working Paper N ${ }^{\circ}$ 908859]. Social Science Research Network, New York, NY. Retrieved September 5, 2009, from http://ssrn.com/abstract=908859

Saito, R. (2003). Determinants of the differential pricing between voting and non-voting shares in Brazil. Brazilian Review of Econometrics, 23(1), 77-111.

Silva, A. L. C. da, \& Subrahmanyam, A. (2007). Dual class premium, corporate governance, and the mandatory bid rule: evidence from the brazilian stock market. Journal of Corporate Finance, $13(1), 1-24$. 